Today we can not underestimate the importance of atomic research (dialectological descriptions of thematic groups of vocabulary, individual words, etc.), so the description of the idiom as a combination of theoretical and practical layers has its place in linguistics. For dialectological science, of course, more significant are the works in which "methodology and methods in action" are presented [1, p. 123].

Thus, the principles of idiom description are focused on taking into account the complex linguistic study of the idiom as a set of a significant number of dialect units. As a methodological basis of modern dialectological description, atomic linguistic interpretation of all language levels of the idiom on the basis of observation of the originality of folk speech determine the modern approach to the synchronous description of dialect stratum.

\title{
References:
}

1. Герд А. С. Введение в этнолингвистику. Курс лекций и хрестоматия. 2-е изд., исправл. СПб.: Изд-во С.-Петерб. ун-та, 2005. 457 с.

2. Гриценко П. Ю. Українська діалектна лексика: реальність і опис (деякі аспекти). Діалектна лексика: лексикологічний, лексикографічний та лінгвогеографічний аспекти. Матеріали доповідей Міжнародної наукової конференції. Глухів, 2005. С. 5-33.

3. Hromko T. V. Methods of collecting material for speech description. Paradigmatic view on the concept of world science: Collection of scientific papers $\langle\Lambda \mathrm{O} Г \mathrm{O} \Sigma$ » with Proceedings of the International Scientific and Practical Conference 2020. Vol. 2. Toronto, Canada: European Scientific Platform. P. 99-101. DOI: 10.36074/21.08.2020.v2.

DOI https://doi.org/10.30525/978-9934-588-90-7-4

\section{ДОСЯГНЕННЯ СУЧАСНОЇ УКРАЇНСЬКОЇ ЛЕКСИКОГРАФІЇ}

\section{Давиденко В. I.}

кандидат філологічних наук, доцент, докторант кафедри прикладної лінгвістики, порівняльного мовознавства та перекладу

Національний педагогічний університет імені М. П. Драгоманова м. Київ, Україна

Значення і вплив лексикографії останнім часом стрімко і невпинно зростає, що обумовлено сучасними запитами суспільства, розвитком, 
вдосконаленням теоретичного підгрунтя та практичних механізмів словникарства, розширенням його можливостей, зокрема, використанням комп'ютерних мереж, електронних баз даних, а також важливими світовими процесами, зокрема глобалізацією, динамічним розвитком співробітництва країн у різних галузях техніки, науки та культури тощо.

Влітку 2020 року з'явився бібліографічний покажчик «Словники української мови» : 1596-2018», укладений за принципом максимального охоплення й представлення видань, у передмові до якого Д. Пилипчук наводить такі статистичні дані: «В 1627-2018 pp. (392 роки) в Україні видано 8036 словників. В 1992-2018 pp. (27 років) в незалежній Україні видано 6883 словника. В 2001-2018 pр. (18 років) в Україні видано 5565 словників» [12, с. 15].

Мета нашого дослідження полягає в аналізі сучасних словникарських праць на засадах кількісної й якісної характеристики, параметричних вимірів та особливостей творів.

Наразі стан української лексикографії характеризується появою багатьох лінгвістичних і енциклопедичних, перекладних і термінологічних словників, довідників для загальних і спеціальних цілей, а також словників змішаного типу тощо.

Якщо ретельно проаналізувати українські словники з погляду протиставлення за критерієм «енциклопедичний/лінгвістичний», то можна стверджувати, що в кінці XX - на початку XXI століть в українській лексикографії переважають енциклопедичні твори, які різняться за масштабністю та важливістю поставлених завдань, специфікою об'єкту опису, формою організації та представлення матеріалу, тематичною складовою, цільовою аудиторією тощо.

До здобутків української лексикографії належать такі різнопланові фундаментальні праці: Енщиклопедія Сучасної Украӥни: у 20 m. (20012018) [5]; Енциклопедичний словник символів Украйни (2017) [6]; Украйнська мова: Енщиклопедія (2015) [15]; Франківська енџииклопедія : y 7 m. (T. 1. - 2016) [18];; Шевченківська енциклопедія (2016) [20] тощо.

Українські лексикографи створили величезну потенційну бібліотеку творів для дітей, різних за принципами укладання, тематикою, призначенням. Причому цільова аудиторія адресатів охоплює від дошкільної (починаючи з 2-3 років), до шкільної й старшої вікової категорії. Наприклад: Моя Україна: найцікавіші факти дітям від 3 років (2016) [8]; Енциклопедія про все на світі у казках та оповіданнях : для дітей дошк. віку (2017) [4];; Азбука ввічливості: історія про маленьку дівчину, ї̈ друга, хороші манери і чарівні перетворення ( 2016) [19] тощо. 
Мовознавці доводять, що «українська лексикографія, традиції якої сягають ще у XVI століття, на початку XXI століття - це сукупність великої кількості словників, різних за відтвореними в них мовами, призначенням, повнотою; центральне місце серед різноманіття лексиконів належить словникам української мови [16, с. III].

Найвідомішим і найбільшим $є$ «Украӥнський тлумачний словник: тезаурус: 250000 слів та словосполучень» (2016) [17], до переваг якого відносяться: повнота представлення сучасних загальновживаних слів i словосполучень, що з'явилися в українській літературній мові в останні роки XX та на початку XXI століття, їх стилістичне забарвлення, поширених термінів, діалектизмів; багата джерельна база й введення у деякі статті енциклопедичних довідок, що є новим для таких праць.

2010 року Український мовно-інформаційний фонд започаткував видання «Словника украӥнської мови: у 20 m» (2010-2020). - T. 1 -10 [13].

За лексикографічною формою всі лінгвістичні словники поділяються на тезауруси, тлумачні словники, конкорданси, глосарії, індекси, тобто частотні словники.

Нещодавно з'явився «Украӥнський лексикон кінцяя XVIII початку XXI ст.: словник - індекс: у 3-х т. : близько 3000 тис. слів» (2017) [16]. Для створення цього словника було обрано 18 філологічних i деяких енциклопедичних словників та зроблено спробу звести їх у єдиний алфавітний покажчик - індекс. Це перший український словник такого типу.

Щодо тезаурусів і глосаріїв, то в українському словникарстві не так багато праць, побудованих за такими принципами, тому тим більше уваги привертають твори такого типу: Жаботинська С. А. Англомовні кліше наукового тексту: Тезаурус (2015) [7]; Сюта Г. М. Цитатний тезаурус украӥнської поетичної мови ХX століття (2017) [14]; Національний освітньо-науковий глосарій (2018) [9] тощо.

Щодо лінгвістичних робіт, то варто зупинитися, зокрема, на таких: Береза Т. Слова, щзо нас збагачують: словник вишуканої украӥнської мови (2016) [2]; Береза Т. Мовою бестселерів : Сучасний словник живої мови (2017) [1] тощо.

Всі ці словники розкривають велич і красу рідної мови, допомагаючи кращому володінню, збагачуючи словниковий запас користувачів тощо

Останнім часом перед українськими лексикографами постало нагальне питання про створення авторитетних і надійних словників, у яких було б представлено терміни нових дисциплін і галузей знань. Наприклад: Електронна освіта: термінологічний словник (2016) [3]; Новітня політична лексика (неологізми, оказіоналізми та інші 
словотвори) (2018) [10]; Педагогіка вищої школи: словник термінів $i$ понять (2018) [12] тощо.

Отже, за спостереженнями вчених, кінець XX - початок XXI століть виявилися «словникарським розмахом» (О. Демська) у розвитку української лексикографії: в плані появи величезної кількості лінгвістичних, енциклопедичних, перекладних, термінологічних словників, довідників, словників змішаного типу тощо.

У сучасній українській лексикографії інноваційні процеси простежуються в укладанні всіх типів словникарських праць.

Мова може йти про те, «що, ймовірно, українська лексикографія за своєю активністю належить вже сьогодні до першої десятки лексикографій світу», а також те, «що Україна - це країна сучасної й високорозвиненої лексикографічної культури та інтенсивного лексикографічного процесу», [12, с. 15-27].

\section{Література:}

1. Береза Т. Мовою бестселерів : Сучасний словник живої мови. Львів: Апріорі, 2017. 800 с.

2. Береза Т. Слова, що нас збагачують: словник вишуканої української мови. Львів: Апріорі, 2016. 382 с.

3. Електронна освіта: термінологічний словник / В. С. Бакіров та ін.; за ред. С. Бакірова. Харків: ХНУ ім. В. Н. Каразіна, 2016. 163 с.

4. Енциклопедія про все на світі у казках та оповіданнях: для дітей дошк. віку / уклад. Ю. М. Карпенко. Київ : Глорія, 2017. 128 с.

5. Енциклопедія Сучасної України : у 20 т. Київ : Поліграфкнига, 2001-2018.

6. Енциклопедичний словник символів України / за ред. О. І. Потапенка, В. П. Коцура, В. В.. Куйбіди. 7-е вид., перероб. та доп. Корсунь-Шевченківський : Всесвіт, 2017. 688 с.

7. Жаботинська С. А. Англомовні кліше наукового тексту: Тезаурус. K., 2015. $72 \mathrm{c}$.

8. Моя Україна: найцікавіші факти дітям від 3 років. Х. : Віват, 2016. 23 c.

9. Національний освітньо-науковий глосарій / уклад. О. М. Топузов та ін.; редкол. В. Г. Кремінь та ін. Київ: Конві принт, 2018. 271 с.

10. Новітня політична лексика (неологізми, оказіоналізми та інші словотвори) / уклад. : Д. Ю. Сизонов, Л. І. Шевченко. Київ: ВПЦ «Київський університет» ім. Т. Шевченка, 2018. Ч. 1. 2018. 115 с.

11. Педагогіка вищої школи: словник термінів і понять / уклад. Г. Ф. Пономарьова, І. М. Толмачова. Харків, 2018. 107 с. 
12. Пилипчук Д. Словники української мови : 1596-2018 : бібліогр. покажчик / упорядник та автор передм. Дмитро Пилипчук. Київ : ВЦ «Просвіта», 2020. 1072 с.

13. Словник української мови : у 20 т. / наук. керівник проекту В. А. Широков ; гол. наук. ред. В. М. Русанівський. Київ : Наукова думка, 2010-2020.

14. Сюта Г. М. Цитатний тезаурус української поетичної мови ХХ століття. Київ: КММ, 2017. 380 с.

15. Українська мова: Енциклопедія. Вид. 4-е, зі змін і допов. К. : Енциклопед. вид-во, 2015. 852 с.

16. Український лексикон кінця XVIII - початку XXI ст. : словникіндекс у 3-х т.: близько 300000 сл. Київ: Вид. дім Дмитра Бураго, 2017. T. 1.669 с.; Т. 2.637 с.; Т. 3.747 с.

17. Український тлумачний словник : тезаурус : 250000 слів та словосполучень / уклад. В. Б. Бусел. Ірпінь ; Київ : Перун, 2016. 1692 с.

18. Франківська енциклопедія : у 7 т. / редкол.: М. Жулинський (голова) та ін. Львів : Світ, 2016.

19. Чуб Н. В. Азбука ввічливості : історія про маленьку дівчину, іï друга, хороші манери і чарівні перетворення. Харків : Віват, 2016. 109 с.

20. Шевченківська енциклопедія : літературні твори / редкол.: М. Жулинський (голова) та ін. Київ : Імекс - ЛТД, 2016. 895 с. 